ISSN 1678-3921

Journal homepage: www.embrapa.br/pab

For manuscript submission and journal contents, access: www.scielo.br/pab

\section{Nutritional parameters of female goat kids fed diets containing detoxified castor bean cake}

\begin{abstract}
The objective of this work was to evaluate the effect of replacing soybean meal (SM) by detoxified castor bean cake (DCC), containing different alkaline solutions, on the nutritional parameters of Saanen and Anglo-Nubian female goat (Capra aegagrus hircus) kids. The treatments consisted of three diets: one based on corn and SM; and two with $\mathrm{DCC}$ with $\mathrm{Ca}(\mathrm{OH})_{2}$ or $\mathrm{NaOH}$. Intake and digestibility data were analyzed in two phases according to the growth curves of the goats, which showed: a linear accelerated growth (phase I, from 60 to 298 days of life) and a reduction in the intensity of body growth (phase II, from 299 to 345 days). During phase I, the goat kids fed DCC with $\mathrm{NaOH}$ showed a lower intake of dry matter (DM) and nutrients. During phase II, there was significant effect of diets on the intake of nutrients, with the exception of ether extract (EE), total digestible nutrients, and metabolizable energy (ME). A diet effect was observed on the digestibility of DM, crude protein, EE, and neutral detergent fiber, mainly for goat kids fed diets with DCC. Despite their lower intake, the diets formulated with DCC do not negatively affect the nutritional performance of female goats kids in both growth phases, since they result in a greater feed efficiency.
\end{abstract}

Index terms: Capra aegagrus hircus, Anglo-Nubian, growth curve, Saanen.

\section{Parâmetros nutricionais de cabritas alimentadas com dieta contendo torta de mamona detoxificada}

Resumo - O objetivo deste trabalho foi avaliar o efeito da substituição do farelo de soja (FS) pela torta de mamona detoxificada (TMD), contendo diferentes soluções alcalinas, nos parâmetros nutricionais de cabritas (Capra aegagrus hircus) Saanen e Anglonubiana. Os tratamentos consistiram de três dietas: uma à base de milho e FS; e duas com TMD por $\mathrm{Ca}(\mathrm{OH})_{2}$ ou $\mathrm{NaOH}$. Os dados de consumo e digestibilidade foram analisados em duas fases, de acordo com as curvas de crescimento das cabritas, que mostraram: crescimento acelerado linear (fase I, de 60 a 298 dias de vida) e redução na intensidade do crescimento corporal (fase II, de 299 a 345 dias). Durante a fase I, as cabritas alimentadas com TMD por $\mathrm{NaOH}$ apresentaram menor consumo de matéria seca (MS) e nutrientes. Durante a fase II, houve efeito das dietas sobre a ingestão de nutrientes, com exceção de extrato etéreo (EE), nutrientes digestíveis totais e energia metabolizável. Observou-se efeito da dieta na digestibilidade da MS, da proteína bruta, do EE e da fibra em detergente neutro, principalmente nas cabritas que consumiram as dietas com TMD. Embora menos consumidas, as dietas formuladas com TMD não afetam negativamente o desempenho nutricional das cabritas em ambas as fases de crescimento, uma vez que resultam em maior eficiência alimentar.

Termos para indexação: Capra aegagrus hircus, Anglonubiana, curva de crescimento, Saanen. 


\section{Introduction}

With the recent increase in the inclusion of biodiesel in the world energy matrix, the by-products or cakes obtained after the extraction of oil from the processed oilseeds have multiplied, being used for a variety of purposes as, for example, for the production of ruminant feeds (Salami et al., 2019). This shows the possibility of integrating the agroenergy and agricultural chains, generating employment and income opportunities, besides allowing to minimize the environmental problems caused by the resulting residues (Araújo et al., 2020b).

In this scenario, studies are necessary to provide information on the best practices for the use of byproducts in ruminant feed. Among the by-products produced by the biodiesel chain, castor bean (Ricinus communis L.) bran and castor bean cake stand out, especially since the cultivation of seeds of this species has been increasing yearly, mainly due to their low demand for water and soil nutrients (Severino et al., 2012).

One of the greatest advantages of using castor bean by-products in ruminant feed is their high protein value. According to Akande et al. (2016), castor bean cake contains 342 to $480 \mathrm{~g}$ crude protein (CP) per kilogram of dry matter; however, since the true protein may be insoluble in neutral detergent, a detoxification process is required, which may decrease this $\mathrm{CP}$ content depending on the alkaline product used (Oliveira et al., 2010). Another nutritional limitation of castor bean by-products is related to the presence of toxic proteins, such as ricin and ricinus agglutinin, in addition to ricin alkaloids and allergenic complexes, which, when ingested by animals, trigger the inactivation of ribosomes, hemolysis, diarrhea, and allergic attacks (Dang \& Van Damme, 2015; Andrade et al., 2019). Despite this, castor bean cake can still be a viable alternative for use as animal feed after its detoxification process (Palmieri et al., 2016; Araújo et al., 2020a).

In dairy goat farming, for example, biodiesel byproducts, mainly castor bean cake, can improve the growth phase and, consequently, the productive potential of future dairy goats (Araújo et al., 2020b). This is paramount for an efficient production in the lactation phase, since healthy, well-nourished, and physiologically well-developed matrices will reflect in healthy gestations and lactations, showing the importance of the rearing phase (Härter et al., 2017). It should be noted that, in dairy farms, goats in the rearing phase represent a great source of expenditure, especially regarding feeding, since they do not produce milk (Lôbo et al., 2017).

Therefore, residues from the biodiesel industry, particularly castor bean cake, can be used as an alternative feed for ruminants, specifically in Brazilian semiarid regions, to replace soybean [Glycine max (L.) Merr.] meal (SM), a feedstuff primarily intended for human consumption and, consequently, with higher production costs (Furtado et al., 2020; Borja et al., 2017; Romero-Huelva et al., 2017).

The objective of this work was to evaluate the effect of replacing soybean meal by detoxified castor bean cake, containing different alkaline solutions, on the nutritional parameters of Saanen and Anglo-Nubian female goat kids.

\section{Materials and Methods}

All animal procedures were conducted according to the regulations of the ethics committee on animal use of Embrapa Caprinos e Ovinos, under protocol number $005 / 2015$. The chemical analyses were performed in the Laboratory of Animal Nutrition and Biochemistry, also of Embrapa Caprinos e Ovinos. The experiment was carried out at the Technological Center for the Production of Goat Milk at Embrapa Caprinos e Ovinos ( $\left.3^{\circ} 44^{\prime} 57.42^{\prime \prime} \mathrm{S}, 40^{\circ} 20^{\prime} 43.50^{\prime \prime} \mathrm{W}\right)$, located in the municipality of Sobral, in the state of Ceará, Brazil. According to the Köppen-Geiger classification, the climate of the region is BSh, hot semiarid.

Twenty-four goat kids (12 Saanen and 12 AngloNubian), with a mean age of $60 \pm 5.0$ days and mean body weight of $16.2 \pm 0.67 \mathrm{~kg}$ were evaluated. The goats were confined and housed in individual stalls made of masonry, with suspended wooden floors and a total area of $5.06 \mathrm{~m}^{2}$. During the pre-experimental period, the goats were identified, treated against ecto- and endoparasites, and vaccinated against rabies. Then, the animals were distributed among treatments, and a 15-day adaptation period to the diets was allowed. The goats were distributed in a randomized complete block design (breed factor) with eight replicates.

The treatments consisted of three diets: the first was formulated with corn (Zea mays L.) and SM; and the other two, with castor cake detoxified by calcium 
hydroxide $\left[\mathrm{Ca}(\mathrm{OH})_{2}\right]$ or sodium hydroxide $(\mathrm{NaOH})$, completely replacing SM. Tifton 85 hay (Cynodon spp.), chopped to $4 \mathrm{~cm}$, was used as a source of forage. The experimental diets were formulated based on the recommendations of the National Research Council (NRC, 2007) for isoproteic and isoenergetic diets. The proportion of ingredients and chemical composition of the diets are shown in Table 1.

The diets were supplied daily at 8 a.m. and 4 p.m., allowing a $10 \%$ surplus supply. Samples were collected from the bulk, concentrate, and leftovers during the entire experimental period, packaged in identified plastic bags, and stored in a freezer at $-18^{\circ} \mathrm{C}$.

At the end of the trial, the samples were thawed and separated according to the evaluation phases (phases I and II) and subjected to pre-drying in a forced-air ventilation oven, at $55^{\circ} \mathrm{C}$, for 24 hours. Phase I (from 60 to 298 days of life) corresponded to a linear period of accelerated growth, and phase II (from 299 to 345

Table 1. Ingredient proportion and chemical composition of the experimental diets fed to female goat (Capra aegagrus hircus) kids in the municipality of Sobral, in the state of Ceará, Brazil.

\begin{tabular}{|c|c|c|c|}
\hline \multirow[t]{3}{*}{ Ingredient } & \multicolumn{3}{|c|}{$\operatorname{Diet}^{(1)}$} \\
\hline & SM & $\begin{array}{l}\text { DCC with } \\
\mathrm{Ca}(\mathrm{OH})_{2}\end{array}$ & $\begin{array}{l}\text { DCC with } \\
\mathrm{NaOH}\end{array}$ \\
\hline & \multicolumn{3}{|c|}{$\begin{array}{l}\text { Proportion of ingredient in the diets } \\
\left(\mathrm{g} \mathrm{kg}^{-1} \text { dry matter }\right)\end{array}$} \\
\hline Tifton 85 hay (Cynodon spp.) & 427.3 & 394.9 & 363.2 \\
\hline Ground corn (Zea mays) & 460.8 & 481.9 & 504.6 \\
\hline Soybean (Glycine max) meal & 57.8 & - & - \\
\hline $\begin{array}{l}\text { Detoxified castor bean (Ricinus } \\
\text { communis) cake }\end{array}$ & - & 83.3 & 82.9 \\
\hline Soybean oil & 45.0 & 39.9 & 39.2 \\
\hline Limestone & 9.1 & 0.01 & 10.1 \\
\hline \multicolumn{4}{|c|}{ Chemical composition ( $\mathrm{g} \mathrm{kg}^{-1}$ dry matter) } \\
\hline Dry matter ( $\mathrm{g} \mathrm{kg}^{-1}$ fresh matter $)$ & 887.7 & 896.1 & 891.8 \\
\hline Organic matter & 942.3 & 897.8 & 938.1 \\
\hline Mineral matter & 57.7 & 102.2 & 61.9 \\
\hline Crude protein & 112.0 & 112.9 & 112.3 \\
\hline Neutral detergent insoluble protein & 13.1 & 13.2 & 12.4 \\
\hline Ether extract & 62.0 & 63.4 & 65.4 \\
\hline Neutral detergent fiber (NDF) & 408.8 & 409.0 & 392.3 \\
\hline NDF corrected for ash and protein & 338.0 & 293.6 & 318.0 \\
\hline Lignin & 30.8 & 32.6 & 30.3 \\
\hline Total digestible nutrients & 664.9 & 658.5 & 663.6 \\
\hline
\end{tabular}

days of life) began at the point of maturation, when a reduction in body growth intensity was observed. The final growth phase was considered to be when the goat kids reached $70 \%$ of the body weight of an adult animal. Halfway through phase I and at the end of phase II, animal feces were collected to estimate the coefficients of digestibility, using the internal acid detergent fiber indicator. For a greater daily representativeness, feces were collected directly from the rectal bulb during five days at different times $(0,3,6$, and 9 hours after the first feeding), being subsequently identified and stored in a freezer at $-18^{\circ} \mathrm{C}$. The feces and feed samples, both with $2.0 \mathrm{~mm}$, were incubated in situ for a period of 240 hours, according to the methodology described by Casali et al. (2008). Degradability was estimated by the in situ technique, using a mestizo sheep weighing 60 $\mathrm{kg}$, which was fed Tifton grass 85 hay and concentrate based on corn and SM.

Consumption and digestibility data were grouped into two periods based on the growth of the goats, and growth curves were analyzed according to breed and diets. Three nonlinear models were tested: logistic, von Bertalanffy's, and Gompertz's. The parameter estimates were obtained using the iterative GaussNewton method with the NLIN procedure of SAS, version 9.3 (SAS Institute Inc., Cary, NC, USA). The tested models were initially evaluated for the two breeds simultaneously, and then for the three diets according to the breeds. Based on the results, it was observed that the logistic model presented the best fit, with a maturation rate $\left(\log _{0.05} \mathrm{k}^{-1}\right)$ of 238 experimental days (298 days of life), stabilizing at $37.83 \mathrm{~kg}$ live weight, with $\mathrm{A}=37.83, \mathrm{k}=0.0045$, and $\mathrm{r}^{2}=0.992(\mathrm{~A})$. The logistic model is represented by: $\mathrm{Y}=\mathrm{A}\left(1+\mathrm{Be}^{-\mathrm{Kt}}\right)-1+\varepsilon$, where $\mathrm{Y}$ is the value understood as body weight in function of age $t$; $A$ is the asymptotic weight; $\mathrm{B}$ is the constant of integration; and $\mathrm{K}$ is the rate of maturity, which is interpreted as a change of weight in relation to weight and maturity, or as an indicator of the speed with which the animal reaches its adult weight.

The goats were weighed at 30-day intervals, always in the morning, aiming to better monitor them in the long evaluation period. At the end of the experiment, final body weight was determined to assess animal performance, which was considered as the difference in the initial and final weights of all goats after 14 hours of fasting from solids. Average daily weight gain 
(ADG), total weight gain (TWG), and feed conversion were calculated based on the collected data.

The concentrations of the alkaline products used for $100 \%$ detoxification of ricin in the crude castor bean cakes were, respectively, $90 \mathrm{~g} \mathrm{~kg}^{-1} \mathrm{Ca}(\mathrm{OH})_{2}$ and 60 $\mathrm{g} \mathrm{kg}^{-1} \mathrm{NaOH}$, which were diluted in $2 \mathrm{~L}$ water using the MOB-400 G2 stationary mixer (Fischer S.A. Indústria \& Comércio, Brusque, SC, Brazil) equipped with a three-phase motor. Since no hemagglutinating activity was observed at those concentrations, i.e., ricinus agglutinin was no longer active, they were used to formulate the diets.

The dried samples were ground in Wiley knife mills. Feed and leftovers were screened using a $1.0-\mathrm{mm}$ sieve for chemical analyses and a $2.0-\mathrm{mm}$ sieve for apparent digestibility. In the feed samples (leftovers and supplied), DM, organic matter, CP, and ether extract (EE) were obtained by methods 934.01, 942.05, 954.01, 920.39, respectively, of Association of Official Analytical Chemists International (AOAC, 2003). The samples were treated with the thermostable alpha-amylase Termamyl (Novozymes Latin America Ltda., Araucária, PR, Brazil) for the neutral detergent fiber (NDF) analysis.

The quantity of total digestible nutrients (TDN) was calculated according to Weiss (1999). The intake of TDN (TDNI) was obtained as described by Sniffen et al. (1992). In the conversion of TDNI into metabolizable energy (ME), $1 \mathrm{~kg}$ TDN was assumed to be equivalent to $4.409 \mathrm{Mcal}$ digestible energy (DE) and $\mathrm{ME}=0.82 \times \mathrm{DE}(\mathrm{NRC}, 2001)$.

Data were initially subjected to Shapiro-Wilk's normality test, to Levene's homoscedasticity test, and to the analysis of variance by the F-test when the presuppositions were met, using the following model: $Y_{\mathrm{ijk}}=\mu+\alpha_{\mathrm{i}}+\beta_{\mathrm{j}}+\mathrm{ek}_{(\mathrm{ij})}$, where $\mathrm{Y}_{\mathrm{ijk}}$ is the dependent variable corresponding to the experimental observation; $\mu$ is the overall mean; $\alpha i$ is the fixed effect of the diets; $\beta_{\mathrm{j}}$ is the fixed effect of the breed; and $\mathrm{ek}_{(\mathrm{ij})}$ is the random error, assuming an independent normal distribution. Statistical analyses were performed using the GLM procedure of the SAS software, version 9.4 (SAS Institute Inc., Cary, NC, USA).

\section{Results and Discussion}

In rearing phase I, a significant effect of the diet was observed on the intake of all nutrients (Table 2). DM intake, expressed in gram per day or as percentage of body weight (BW), was higher for the goats fed SM and DCC with $\mathrm{Ca}(\mathrm{OH})_{2}$, whereas the intake of NDF was higher for the goats fed only SM. Animals consuming DCC with $\mathrm{Ca}(\mathrm{OH})_{2}$ and $\mathrm{NaOH}$ had a higher intake of TDN of 790.25 and $748.69 \mathrm{~g}$ per day, respectively, and also a higher intake of ME of 13.71 and $12.99 \mathrm{MJ}$ per day.

During phase I, a diet effect was also found on the digestibility of DM and other nutrients, but without any breed effect (Table 2). Regardless of the detoxification process, diets containing castor bean cake had the highest DM, CP, and NDF digestibility, when compared with those with SM. Throughout this phase, DM digestibility was above $73 \%$ for the diets with the castor bean cakes, and better digestibility values were observed for all nutrients. For EE digestibility, the diet with DCC with $\mathrm{Ca}(\mathrm{OH})_{2}$ did not differ from that with SM.

During rearing phase II, there was a significant diet effect on the intake of almost all nutrients, with the exception of EE, TDN, and ME (Table 3). DM intake, expressed as either gram per day or BW percentage, was higher for goats fed SM. Diets with DCC showed the highest nutrient digestibility (Table 3), except for EE, whereas the one with DCC with $\mathrm{NaOH}$ presented a higher digestibility than that with SM and that with DCC with $\mathrm{Ca}(\mathrm{OH})_{2}$ had intermediate values.

The higher digestibility of the diets with DCC and, consequently, the better feed conversion by the goats fed these diets may be associated with a possible "ammonization" during the detoxification process, as alkaline products act on the fibrous plant cell fraction, causing hydrogen bonds to rupture and cellulose molecules to expand and become more susceptible to the action of cellulolytic enzymes. The alkaline products also led to hemicellulose solubilization due to the rupture of ester-like bonds between hemicellulose and lignin (Campos et al., 2020).

According to Santos et al. (2017), when certain feeds are subjected to alkali treatment, gains of 20 to $50 \%$ in vitro DM digestibility and increased DM intake are usually observed; however, in the present study, a reduced intake was verified for goats fed DCC with $\mathrm{NaOH}$. Probably, the sodium from the hydroxide played the role of an intake controller, since the DCC with $\mathrm{NaOH}$ had $2.92 \%$ sodium in DM (Table 1), which is a very high value, especially considering that this 
cake accounted for $13.66 \%$ of the natural matter of the feed concentrate. Furthermore, the presence of large amounts of this ion in the rumen of animals causes changes in rumen molarity, which can harm the environment and reduce DM intake (Allen, 2020).
There was no diet effect on ADG or TWG. The lower intake of the diets with DCC, which is associated with the best digestibility, was believed to have caused the similarity between both parameters (Table 4). In addition, feed conversion was significantly

Table 2. Intake of dry matter (DM), crude protein (CP), ether extract (EE), neutral detergent fiber (NDF), total digestible nutrients (TDN), and metabolizable energy (ME), as well as digestibility of DM, CP, EE and NDF, by female dairy goat (Capra aegagrus hircus) kids fed diets containing detoxified castor bean (Ricinus communis) cake instead of soybean (Glycine max) meal during rearing phase I (from 60 to 298 days of life), in the municipality of Sobral, in the state of Ceará, Brazil ${ }^{(1)}$.

\begin{tabular}{|c|c|c|c|c|c|c|c|c|}
\hline \multirow[t]{2}{*}{ Intake } & \multicolumn{3}{|c|}{$\operatorname{Diet}^{(2)}$} & \multirow[t]{2}{*}{$\mathrm{SEM}^{(3)}$} & \multicolumn{2}{|c|}{ Breed } & \multicolumn{2}{|c|}{ P-value } \\
\hline & SM & DCC 1 & DCC 2 & & Saanen & Anglo-Nubian & Diet & Breed \\
\hline \multicolumn{9}{|c|}{ Intake phase I (from 60 to 298 days of life) } \\
\hline DM (g per day) & $998.96 \mathrm{a}$ & $912.58 \mathrm{a}$ & $791.16 b$ & 36.14 & 921.31 & 880.49 & $<0.05$ & 0.341 \\
\hline $\mathrm{DM}(\mathrm{BW} \%)^{(4)}$ & $3.26 \mathrm{a}$ & $3.05 \mathrm{a}$ & $2.65 b$ & 0.10 & 3.02 & 2.96 & $<0.05$ & 0.624 \\
\hline CP (g per day) & $114.37 \mathrm{a}$ & $106.69 \mathrm{a}$ & $92.21 b$ & 4.23 & 106.24 & 102.21 & $<0.05$ & 0.376 \\
\hline EE (g per day) & $63.82 \mathrm{a}$ & $60.66 \mathrm{ab}$ & $54.75 b$ & 2.50 & 61.14 & 58.35 & $<0.05$ & 0.376 \\
\hline NDF (g per day) & $390.12 \mathrm{a}$ & $347.98 b$ & $308.38 b$ & 1.98 & 348.73 & 328.70 & $<0.05$ & 0.487 \\
\hline TDN (g per day) & $661.63 b$ & $790.25 a$ & $748.69 \mathrm{a}$ & 27.87 & 765.87 & 781.45 & $<0.05$ & 0.231 \\
\hline ME (MJ per day) & $11.48 \mathrm{~b}$ & $13.71 \mathrm{a}$ & $12.99 \mathrm{a}$ & 1.32 & 12.45 & 12.57 & $<0.05$ & 0.143 \\
\hline \multicolumn{9}{|c|}{ Digestibility phase I (from 60 to 298 days of life) } \\
\hline $\mathrm{DM}\left(\mathrm{g} \mathrm{kg}^{-1} \mathrm{FM}\right)^{(5)}$ & $662 b$ & $730 \mathrm{a}$ & $732 \mathrm{a}$ & 1.25 & 716 & 710 & $<0.050$ & 0.456 \\
\hline $\mathrm{CP}\left(\mathrm{g} \mathrm{kg}^{-1} \mathrm{DM}\right)$ & $727 b$ & $775 \mathrm{a}$ & $771 \mathrm{a}$ & 1.07 & 761 & 754 & $<0.050$ & 0.424 \\
\hline $\mathrm{EE}\left(\mathrm{g} \mathrm{kg}^{-1} \mathrm{DM}\right)$ & $786 b$ & $821 b$ & $835 \mathrm{a}$ & 1.29 & 815 & 814 & $<0.050$ & 0.400 \\
\hline $\mathrm{NDF}\left(\mathrm{g} \mathrm{kg}^{-1} \mathrm{DM}\right)$ & $616 b$ & $659 a$ & $651 \mathrm{a}$ & 1.53 & 638 & 646 & $<0.050$ & 0.382 \\
\hline
\end{tabular}

${ }^{(1)}$ Means followed by equal letters, in the rows, do not differ by Tukey's test, at 5\% probability. (2)SM, soybean meal (control); DCC 1 , castor bean cake detoxified by calcium hydroxide; and DCC 2 , castor bean cake detoxified by sodium hydroxide. ${ }^{(3)}$ Standard error of the mean. ${ }^{(4)}$ Percentage of body weight. ${ }^{(5)}$ Fresh matter.

Table 3. Intake of dry matter (DM), crude protein (CP), ether extract (EE), neutral detergent fiber (NDF), total digestible nutrients (TDN), and metabolizable energy (ME), as well as digestibility of DM, CP, EE, and NDF, by female dairy goat (Capra aegagrus hircus) kids fed diets containing detoxified castor bean (Ricinus communis) cake instead of soybean (Glycine max) meal during rearing phase II (from 299 to 345 days of life), in the municipality of Sobral, in the state of Ceará, Brazil ${ }^{(1)}$.

\begin{tabular}{|c|c|c|c|c|c|c|c|c|}
\hline \multirow[t]{2}{*}{ Intake } & \multicolumn{3}{|c|}{$\operatorname{Diet}^{(2)}$} & \multirow[t]{2}{*}{$\mathrm{SEM}^{(3)}$} & \multicolumn{2}{|c|}{ Breed } & \multicolumn{2}{|c|}{ P-value } \\
\hline & $\mathrm{SM}$ & DCC 1 & DCC 2 & & Saanen & Anglo-Nubian & Diet & Breed \\
\hline \multicolumn{9}{|c|}{ Intake phase II (from 299 to 345 days of life) } \\
\hline DM (g per day) & $1,045.02 \mathrm{a}$ & $906.22 b$ & $892.89 b$ & 27.56 & 952.61 & 943.48 & $<0.05$ & 0.777 \\
\hline $\mathrm{DM}(\mathrm{BW} \%)^{(4)}$ & $2.54 \mathrm{a}$ & $2.17 \mathrm{~b}$ & $2.13 b$ & 0.09 & 2.34 & 2.22 & $<0.05$ & 0.290 \\
\hline CP (g per day) & $121.01 \mathrm{a}$ & $106.79 b$ & $104.31 b$ & 3.38 & 111.77 & 109.64 & $<0.05$ & 0.593 \\
\hline EE (g per day) & 67.93 & 60.86 & 62.28 & 2.05 & 64.26 & 63.12 & 0.059 & 0.636 \\
\hline NDF (g per day) & $401.00 \mathrm{a}$ & $345.94 b$ & $322.30 b$ & 10.51 & 355.32 & 357.52 & $<0.05$ & 0.858 \\
\hline TDN (g per day) & 691.02 & 693.09 & 685.60 & 33.21 & 695.76 & 694.87 & 0.052 & 0.754 \\
\hline ME (MJ per day) & 11.99 & 12.02 & 11.89 & 1.98 & 12.04 & 12.10 & 0.062 & 0.876 \\
\hline \multicolumn{9}{|c|}{ Digestibility phase II (from 299 to 345 days of life) } \\
\hline $\mathrm{DM}\left(\mathrm{g} \mathrm{kg}^{-1} \mathrm{FM}\right)^{(5)}$ & $65.38 \mathrm{~b}$ & $71.78 \mathrm{a}$ & $73.21 \mathrm{a}$ & 1.26 & 69.63 & 70.50 & $<0.050$ & 0.558 \\
\hline $\mathrm{CP}\left(\mathrm{g} \mathrm{kg}^{-1} \mathrm{DM}\right)$ & $71.40 \mathrm{~b}$ & $76.20 \mathrm{a}$ & $76.51 \mathrm{a}$ & 1.26 & 73.90 & 75.42 & $<0.050$ & 0.308 \\
\hline $\mathrm{EE}\left(\mathrm{g} \mathrm{kg}^{-1} \mathrm{DM}\right)$ & $76.72 b$ & $80.13 \mathrm{ab}$ & $81.86 \mathrm{a}$ & 1.42 & 78.94 & 80.20 & $<0.050$ & 0.451 \\
\hline NDF $\left(\mathrm{g} \mathrm{kg}^{-1} \mathrm{DM}\right)$ & $60.44 b$ & $74.09 \mathrm{a}$ & $74.71 \mathrm{a}$ & 1.52 & 68.32 & 70.85 & $<0.050$ & 0.255 \\
\hline
\end{tabular}

${ }^{(1)}$ Means followed by equal letters, in the rows, do not differ by Tukey's test, at 5\% probability. (2)SM, soybean meal (control); DCC 1 , castor bean cake detoxified by calcium hydroxide; and DCC 2, castor bean cake detoxified by sodium hydroxide. ${ }^{(3)}$ Standard error of the mean. ${ }^{(4)}$ Percentage of body weight.

${ }^{(5)}$ Fresh matter. 
Table 4. Average daily gain (ADG), total weight gain (TWG), and feed conversion (FC) of female dairy goat (Capra aegagrus hircus) kids fed diets containing detoxified castor bean (Ricinus communis) cake instead of soybean (Glycine max) meal during rearing phase I (from 60 to 345 days of life), in the municipality of Sobral, in the state of Ceará, Brazil( ${ }^{(1)}$.

\begin{tabular}{|c|c|c|c|c|c|c|c|c|}
\hline \multirow[t]{2}{*}{ Item } & \multicolumn{3}{|c|}{$\operatorname{Diet}^{(2)}$} & \multirow[t]{2}{*}{$\mathrm{SEM}^{(3)}$} & \multicolumn{2}{|c|}{ Breed } & \multicolumn{2}{|c|}{ P-value } \\
\hline & SM & DCC 1 & DCC 2 & & Saanen & Anglo-Nubian & Diet & Breed \\
\hline ADG (g per day) & $109.64 \mathrm{a}$ & $107.69 \mathrm{a}$ & $99.49 \mathrm{a}$ & 6.70 & 107.54 & 103.67 & 0.534 & 0.622 \\
\hline TWG (kg) & $25.82 \mathrm{a}$ & $26.07 \mathrm{a}$ & $25.66 \mathrm{a}$ & 1.67 & 26.13 & 25.57 & 0.984 & 0.775 \\
\hline FC $\left(\mathrm{kg} \mathrm{kg}^{-1} \text { intake of DM) }\right)^{(4)}$ & $9.36 \mathrm{~b}$ & $8.56 \mathrm{a}$ & $8.59 \mathrm{a}$ & 0.63 & 8.86 & 8.81 & $<0.050$ & 0.873 \\
\hline
\end{tabular}

${ }^{(1)}$ Means followed by equal letters, in the rows, do not differ by Tukey's test, at $5 \%$ probability. ${ }^{(2)}$ SM, soybean meal (control); DCC 1 , castor bean cake detoxified by calcium hydroxide; and DCC 2 , castor bean cake detoxified by sodium hydroxide. ${ }^{(3)}$ Standard error of the mean. ${ }^{\left({ }^{(4)}\right.}$ Dry matter.

influenced by the diets, but not by the breeds. Goats fed diets with DCC showed a better feed conversion ratio, which was probably related to their lower ingestion (Tables 2 and 3). Despite the lower intake of DM during phase I, the goats fed DCC with $\mathrm{NaOH}$ used the diet more efficiently. The animals showed the highest weight gains during the first phase because their growth was accelerated. DM intake influenced $\mathrm{CP}$ intake results due to the direct relationship between them, considering that the diets were isoproteic. Goats fed the diet with DCC with $\mathrm{NaOH}$ had the lowest CP intake during rearing phase I; however, this value represented $11.65 \%$ CP through DM intake, which also corresponds to the recommended value for animals of this category during their growth phase (NRC, 2007). Regarding EE intake, the obtained values were up to $6 \%$ higher for all treatments and rearing phases than the maximum recommended for ruminants (NRC, 2007); these increases were due to the addition of soybean oil to the diets in order to meet the energy requirements of the animals.

According to NRC (2007), the TDN intake for the category of growing goats to obtain a daily body weight gain of $100 \mathrm{~g}$ is of 420 to $500 \mathrm{~g}$ per day. This range is lower than the TDN intake of goats in the present study, where an average of $733.52 \mathrm{~g}$ per day was obtained for an ADG of $105.60 \mathrm{~g}$ per day in phase I.

It is interesting to note that the evaluated breeds did not differ regarding performance (Table 4). This results contradicts the data available in the literature, which considers Anglo-Nubian goats as dual-purposed, and, therefore, with an expected greater weight gain than Saanen goats (Lôbo et al., 2017).

The results obtained in the present study justify the potential use of DCC, regardless of the alkaline product applied for its detoxification, first because the inclusion of castor bean cake alone does not affect the performance of goats during the rearing phase and second because this cake is currently sold as an organic fertilizer in agribusiness, with a low profit (Araújo et al., 2020b). As an alternative source of protein, DCC can replace other traditional feeds, such as SM, which are considered noble and, therefore, more expensive, leading to a reduction in production costs. Another important factor to be considered when managing castor bean cake is that the treatment with sodium hydroxide presents some drawbacks, such as requiring a greater care in handling and causing excess sodium in the diet, feces, and urine, as well as environmental contamination problems (Araújo et al., 2020c). However, the $\mathrm{DCC}$ with $\mathrm{Ca}(\mathrm{OH})_{2}$ can also cause excess calcium in the diet, leading to urinary calculi; moreover, in cases where the calcium:phosphorus ratio is above 6:1, there is a reduction in the absorption of phosphate by dairy goats (Wilkens \& Muscher-Banse, 2020). Despite these observations, the results show that the use of DCC in goat diets during their growth phase is promising, allowing to replace SM without compromising animal performance.

\section{Conclusions}

1. The replacement of soybean (Glycine max) meal with detoxified castor bean (Ricinus communis) cake, containing calcium hydroxide or sodium hydroxide alkaline solutions, is a viable alternative for feeding Saanen and Anglo-Nubian female goat (Capra aegagrus hircus) kids during their growth phase.

2. Although their intake is lower, diets formulated with detoxified castor bean cake instead of soybean meal do not negatively affect the performance of the female goat kids in both growth phases evaluated (60 to 298 and 299 to 345 days of life), regardless of the breed and of the alkaline product used for castor bean cake detoxification. 


\section{Acknowledgments}

To Coordenação de Aperfeiçoamento de Pessoal de Nível Superior (Capes), for financing the project and for postgraduate scholarships; to Embrapa Caprinos e Ovinos, for all the technical and installation/ infrastructure support; to Conselho Nacional de Desenvolvimento Científico e Tecnológico (CNPq), for grants (Finance Code 001); and to Agroindústria OLVEq Ltda., for donating the castor bean cake for conducting the research.

\section{References}

AKANDE, T.O.; ODUNSI, A.A.; AKINFALA, E.O. A review of nutritional and toxicological implications of castor bean (Ricinus communis L.) meal in animal feeding systems. Journal of Animal Physiology and Animal Nutrition, v.100, p.201-210, 2016. DOI: https://doi.org/10.1111/jpn.12360.

ALLEN, M.S. Review: control of feed intake by hepatic oxidation in ruminant animals: integration of homeostasis and homeorhesis. Animal, v.14, p.s55-s64, 2020. DOI: https://doi.org/10.1017/ S1751731119003215.

ANDRADE, I.R.A. de; CÂNDIDO, M.J.D.; POMPEU, R.C.F.F.; FEITOSA, T.S.; BOMFIM, M.A.D.; SALLES, H.O.; EGITO, A.S. do. Inactivation of lectins from castor cake by alternative chemical compounds. Toxicon, v.160, p.47-54, 2019. DOI: https://doi.org/10.1016/j.toxicon.2019.02.003.

AOAC. Association of Analytical Chemists International. Official Methods of Analysis of AOAC International. 17th ed. $2^{\text {nd }}$ rev. Gaithersburg, 2003. Official Methods 920.39, 934.01, 942.05, 954.01.

ARAÚJO, R.A. de; POMPEU, R.C.F.F.; CÂNDIDO, M.J.D.; ROGÉRIO, M.C.P.; LUCAS, R.C.; MARANHÃO, S.R.; SANTOS NETO, C.F. dos; NEIVA, J.N.M. Detoxified castor in the diets of dairy goats: I. Effects on intake, digestibility, and renal and hepatic parameters. Revista Brasileira de Zootecnia, v.49, e20190141, 2020a. DOI: https://doi.org/10.37496/rbz4920190141.

ARAÚJO, R.A. de; POMPEU, R.C.F.F.; ROGÉRIO, M.C.P.; MARTINS, E.C.; CÂNDIDO, M.J.D.; SANTOS NETO, C.F. dos; FURTADO, R.N.; SILVA, L.N.C. da; NEIVA, J.N.M. Economic-financial analysis of the use of the detoxified castor by alkaline solutions I: production of arrays of dairy goats. Semina: Ciências Agrárias, v.41, p.2703-2720, 2020b. DOI: https://doi.org/10.5433/1679-0359.2020v41n6p2703.

ARAÚJO, R.A.; NEIVA, J.N.M.; ROGÉRIO, M.C.P.; CÂNDIDO, M.J.D.; EGITO, A.S.; PEREIRA, P.L.; LUCAS, R.C.; POMPEU, R.C.F.F. Destoxificação e perfil nutricional da torta de mamona destoxificada por diferentes soluções alcalinas. Arquivo Brasileiro de Medicina Veterinária e Zootecnia, v.72, p.19471958, 2020c. DOI: https://doi.org/10.1590/1678-4162-11418.

BORJA, M.S.; OLIVEIRA, R.L.; SILVA, T.M.; BEZERRA, L.R.; NASCIMENTO JÚNIOR, N.G.; BORJA, A.D.P. Effectiveness of calcium oxide and autoclaving for the detoxification of castor seed meal in finishing diets for lambs. Animal Feed Science and Technology, v.231, p.76-78, 2017. DOI: https://doi.org/10.1016/j. anifeedsci.2017.07.001.

CAMPOS, F.P.; NUSSIO, L.G.; SARMENTO, P.; DANIEL, J.L.P.; LIMA, C.G. Effects of addition of different sources and doses of sugars on in vitro digestibilities of dry matter, fibre and cell wall monosaccharides of corn silage in ruminants. Animal, v.14, p.1667-1675, 2020. DOI: https://doi.org/10.1017/ S1751731120000385.

CASALI, A.O.; DETMANN, E.; VALADARES FILHO, S. de C.; PEREIRA, J.C.; HENRIQUES, L.T.; FREITAS, S.G. de; PAULINO, M.F. Influência do tempo de incubação e do tamanho de partículas sobre os teores de compostos indigestíveis em alimentos e fezes bovinas obtidos por procedimentos in situ. Revista Brasileira de Zootecnia, v.37, p.335-342, 2008. DOI: https://doi.org/10.1590/S1516-35982008000200021.

DANG, L.; VAN DAMME, E.J.M. Toxic proteins in plants. Phytochemistry, v.117, p.51-64, 2015. DOI: https://doi. org/10.1016/j.phytochem.2015.05.020.

FURTADO, R.N.; POMPEU, R.C.F.F.; CÂNDIDO, M.J.D.; PEREIRA, E.S.; LOPES, M.N.; ROGÉRIO, M.C.P. Intake, digestibility and nitrogen balance in sheep fed diets containing detoxified castor cake. Revista Ciência Agronômica, v.51, e20175992, 2020. DOI: https://doi.org/10.5935/18066690.20200012 .

HÄRTER, C.J.; LIMA, L.D.; SILVA, H.G.O.; CASTAGNINO, D.S.; RIVERA, A.R.; RESENDE, K.T.; TEIXEIRA, I.A.M.A. Energy and protein requirements for maintenance of dairy goats during pregnancy and their efficiencies of use. Journal of Animal Science, v.95, p.4181-4193, 2017. DOI: https://doi.org/10.2527/ jas2017.1490.

LÔBO, A.M.B.O.; LÔBO, R.N.B.; FACÓ, O.; SOUZA, V.; ALVES, A.A.C.; COSTA, A.C.; ALBUQUERQUE, M.A.M. Characterization of milk production and composition of four exotic goat breeds in Brazil. Small Ruminant Research, v.153, p.9-16, 2017. DOI: https://doi.org/10.1016/j.smallrumres.2017.05.005.

NRC. National Research Council. Nutrient requirements of dairy cattle. $7^{\text {th }}$ rev. ed. Washington: National Academies Press, 2001. 381p. DOI: https://doi.org/10.17226/9825.

NRC. National Research Council. Nutrient requirements of small ruminants: sheep, goats, cervids, and new world camelids. Washington: The National Academies Press, 2007.

OLIVEIRA, A.S. de; OLIVEIRA, M.R.C.; CAMPOS, J.M.S.; LANA, R.P.; MACHADO, O.L.T.; RETAMAL, C.A.; DETMANN, E.; VALADARES FILHO, S.C. In vitro ruminal degradation of ricin and its effect on microbial growth. Animal Feed Science and Technology, v.157, p.41-54, 2010. DOI: https://doi.org/10.1016/j.anifeedsci.2010.01.006.

PALMIERI, A.D.; CARVALHO, G.G.P. de; TOSTO, M.S.L.; LEITE, V.M.; SANTOS, S.A.; BORJA, M.S.; AZEVÊDO, J.A.G.; FREITAS JÚNIOR, J.E. de; LEITE, L.C.; AYRES, M.C.C.; RUFINO, L.M. de A. Nutritional and productive performance of goats kids fed diets with detoxified castor meal. Animal Feed Science and Technology, v.216, p.81-92, 2016. DOI: https://doi.org/10.1016/j.anifeedsci.2016.03.015. 
ROMERO-HUELVA, M.; RAMÍREZ-FENOSA, M.A.; PLANELLES-GONZÁLEZ， R.; GARCÍA-CASADO, P.; MOLINA-ALCAIDE, E. Can by-products replace conventional ingredients in concentrate of dairy goat diet? Journal of Dairy Science, v.100, p. 4500-4512, 2017. DOI: https://doi.org/10.3168/ jds.2016-11766.

SALAMI, S.A.; LUCIANO, G.; O'GRADY, M.N.; BIONDI, L.; NEWBOLD, C.J.; KERRY, J.P.; PRIOLO, A. Sustainability of feeding plant by-products: a review of the implications for ruminant meat production. Animal Feed Science and Technology, v.251, p.37-55, 2019. DOI: https://doi.org/10.1016/j. anifeedsci.2019.02.006.

SANTOS, F.N. de S.; CARNEIRO, M.S. de S.; ARAÚJO, R.A. de; COSTA, C. dos S.; SILVA, L. de N.C. da; SILVA, I.R. da; SALES, R. de O.; BARBOSA, J. dos S.R.; SOUSA, G.O.C. Ammoniation on the quality of tropical grasses: a review. Revista Brasileira de Higiene e Sanidade Animal, v.11, p.131-143, 2017. DOI: https://doi.org/10.5935/1981-2965.20170014.

SEVERINO, L.S.; AULD, D.L.; BALDANZI, M.; CANDIDO, M.J.D.; CHEN, G.; CROSBY, W.; TAN, D.; HE, X.H.; LAKSHMAMMA, P.; LAVANYA, C.; MACHADO, O.L.T.;
MIELKE, T.; MILANI, M.; MILLER, T.D.; MORRIS, J.B.; MORSE, S.A.; NAVAS, A.A.; SOARES, D.J.; SOFIATTI, V.; WANG, M.L.; ZANOTTO, M.D.; ZIELER, H. A review on the challenges for increased production of castor. Agronomy Journal, v.104, p.853-880, 2012. DOI: https://doi.org/10.2134/ agronj2011.0210.

SNIFFEN, C.J.; O'CONNOR, J.D.; VAN SOEST, P.J.; FOX, D.G.; RUSSELL, J.B. A net carbohydrate and protein system for evaluating cattle diets: II. carbohydrate and protein availability. Journal of Animal Science, v.70, p.3562-3577, 1992. DOI: https://doi.org/10.2527/1992.70113562x.

WEISS, W.P. Energy prediction equations for ruminant feeds. In: CORNELL NUTRITION CONFERENCE FOR FEED MANUFACTURERS, 61., 1999, Ithaca. Proceedings. Ithaca: Cornell University, 1999. p.176-185.

WILKENS, M.R.; MUSCHER-BANSE, A.S. Review: regulation of gastrointestinal and renal transport of calcium and phosphorus in ruminants. Animal, v.14, p.s29-s43, 2020. DOI: https://doi.org/10.1017/S1751731119003197. 